\title{
Komunikasi Pemasaran Sarana Upakara Di Kawasan Pasar Tradisonal
}

\author{
Oleh: \\ Ni Made Ayu Sri Wulandari \\ Universitas Hindu Indonesia Denpasar \\ Email: wulan@unhi.ac.id
}

\begin{abstract}
This study try to explain the description of the marketing mix activities, barriers and implications of marketing communication activities. The aim is to analyze the importance and impact of marketing in the business world by traders to attract consumers so that traders do not suffer losses. The research approach is qualitative with the case study method and uses interview techniques, field observations, and documentation. The main sources consist of traders and consumers who buy ceremony facilities who are directly involved in marketing communication activities. The results of this study explain that traders select and carry out elements in the marketing mix to carry out marketing communications, including products, prices, promotions, locations. The marketing mix that is carried out by traders provides exposure to target markets effectively which has an impact on consumer awareness by making repeat buyers. Barriers that occur in marketing communication activities consist of language disorders, physical problems, and technical problems. The implications that occur in communication activities experience positive and negative impacts including the ease of obtaining the need for ceremonial facilities positively, but negatively resulting in the fading of the cultural values of the tablejitan tradition in ceremonial preparation activities because they prefer to buy rather than make.
\end{abstract}

\section{Key words: Marketing Communications, Consumers and Traders}

\section{Pendahuluan}

Budaya di Pulau Bali mendapatkan pengaruh besar dari agama yang dianut sebagian besar warganya yaitu Agama Hindu. Agama Hindu memiliki 3 (tiga) dasar yang dipergunakan sebagai dasar dalam melaksanakan kegiatan sehari-hari yang dikenal dengan nama 3 (tiga) kerangka dasar Agama Hindu yang terdiri dari tattwa, susila dan upacara. Tattwa ialah filsafat yang dijadikan dasar dalam menjalani kehidupan. Nilai tattwa ini diperoleh dari kitab suci yang mengajarkan kebenaran dan aturan tingkah laku bagi pemeluknya. Susila adalah aspek pembentukan sikap keagamaan yang menuju pada sikap dan prilaku yang baik sehingga manusia memiliki kebajikan dan kebijaksanaan. Sedangkan upacara ialah tata cara pelaksanaan ajaran agama yang diwujudkan dalam tradisi upacara sebagai wujud simbolis komunikasi manusia dengan Tuhan. 
Pada dasarnya acara dalam agama Hindu terbagi menjadi dua bagian yaitu upacara dan upakara. Upacara berkaitan dengan tata cara ritual, seperti tata cara sembhyang, harihari suci keagamaan dan rangkain upacara. Sebaliknya, upakara adalah sarana yang dipersembahkan dalam upacara keagamaan yang sering disebut banten. Banten merupakan salah satu sarana bagi umat Hindu dalam menghubungkan diri dengan Tuhan. Banten terdiri dari beberapa bagian pendukung lainnya, antara lain, buah-buahan, jajanan (jaje Bali), serta jejaitan. Banten juga diidentikkan dengan kaum perempuan oleh sebagian besar masyarakat. Hal ini merujuk pada proses pembuatan banten yang sebagian besar dilakukan oleh kaum perempuan

Pada perkembangannya, banten kemudian menjadi salah satu komoditi yang dapat diperjualbelikan oleh kelompok atau perorangan yang kemudian dikenal dengan istilah tukang banten. Tukang banten merupakan seorang atau sekelompok orang yang memiliki keahlian dibidang banten (mulai dari proses mejejaitan hingga metanding) yang secara jelas mengetahui pemaknaan, penempatan, dan fungsi banten serta sudah dipercayai oleh masyarakat dilingkungannya dalam semua rangkaian upacara keagamaan. Selain tukang banten, ada pula sejumlah perempuan Bali yang menjadikan kemampuan mejejaitannya untuk memperoleh tambahan penghasilan atau bahkan menjadi pekerjaan utama dengan membuat lalu menjual kelengkapan banten (bermacam-macam jejaitan).

Dalam pelaksanaanya kegiatan keagamaan ini memunculkan banyaknya industri baru sebagai jawaban atas kebutuhan yang diperlukan untuk memenuhi kebutuhan keagamaan. Kebutuhan-kebutuhan yang muncul sebagai dampak perkembangan teknologi dan banyaknya kaum perempuan yang bekerja yang mengakibatkan sistem kerja yang cepat, praktis dan hemat namun tidak mengurangi makna dari persembahan yang akan dihaturkan umat Hindu dalam melakukan upacara keagamaan

Kegiatan keagamaan ini yang memerlukan banyak sarana dan prasarana yang khusus dibuat masyarakat Hindu yang digunakan sebagai persembahan seperti misalnya tumpeng dengan segala bentuk dan ukuran, selain itu ada pula jejaitan yang terbuat dari janur atau lontar sebagai pelengkap dalam membuat bebantenan. Hal tersebut membentuk komunikasi yang aktif terhadap transaksi jual-beli dalam penyedia sarana Upakara yang saat ini mulai banyak kita jumpai banyak di pasar-pasar tradisional di Kota Mataram. 
Peningkatan permintaan akan kebutuhan sarana Upakara yang memunculkan akibat dari muncul pedagang-pedagang baru yang menjual sarana Upakara di kawasan sekitar pasar tradisional di Kota Mataram. Sehingga membuat persaingan antar penjual satu dengan lainnya. Proses komunikasi serta pemasaran dalam transaksi terhadap produk yang dijual sangatlah berpangruh penting akan sebuah peningkatan terhadap minat dari pembeli, penggunaan media yang tepat dalam pemasaran sangatlah berpengaruh untuk menjaring konsumen lebih luas, salah satu hal yang harus dilakukakan ialah melakukan kegiatan komunikasi pemasaran yang tepat sebagai upaya dalam mempertahankan daya saing dalam usaha.

Komunikasi pemasaran dapat dipahami dengan menguraikan dua unsur pokok yaitu komunikasi dan pemasaran. Komunikasi adalah proses pemikiran dan pemahaman disampaikan antar individu atau antara organisasi dengan individu. Pemasaran adalah sekumpulan kegiatan dimana perusahaan dan organisasi lainnya mentransfer nilai-nilai (pertukaran) antara mereka dengan pelanggannya. Dari dua pengertian kata tersebut dapat disimpulkan bahwa komunikasi pemasaran adalah sarana dimana perusahaan berusaha menginformasikan, membujuk, dan mengingatkan konsumen secara langsung maupun tidak langsung tentang produk dan merek yang dijual. Oleh sebab itu, maka perlu ada kajian terkait " Komunikasi pemasaran sarana upakara di kawasan pasar tradisional Kota Mataram".

\section{Metode Penelitian}

Penelitian ini dirancang dengan jenis penelitian kualitatif interpretatif merupakan penelitian yang berlandaskan pada filsafat post positivisme, digunakan suatu objek yang ilmiah dimana peneliti adalah sebagai instrumen kunci (Sugiyono, 2014:15). Dalam penelitian ini Motede kualitatif bertujuan untuk menganalisis dan mengkaji secara lebih mendalam tentang Komunikasi Pemasaran sarana upakara di kawasan pasar tradisional Kota Mataram.

Jenis data yang digunakan dalam penelitian ini berupa data kualitatif dan data kuantitatif. Data kualitatif disini diperoleh dari hasil penelitian yang dilakukan dengan cara observasi dan wawancara antara pedagang dan konsumen. Sedangkan data kuantitaif diperoleh dari data statistik dan bentuk angka pada harga produk yang dijual. 
Teknik pengumpulan data yang digunakan dalam penelitian ini dilakukan melalui observasi, wawancara, dan dokumentasi. Observasi yang akan digunakan dalam penelitian ini ialah observasi partisipan aktif, yaitu peneliti ikut melakukan apa yang dilakukan oleh subyek penelitian dengan cara peneliti terjun langsung ke lokasi penelitin dalam mengidenfikasi aktivitas sosial yang berhubungan dengan variable pada penelitian ini Penelitian ini menggunakan wawancara kombinasi (gabungan dari wawancara terstruktur dan wawancara bebas) dimana wawancara dilakukan secara bebas namun mendapatkan data yang maksimal dari subyek penelitian Dokumentasi dalam penelitian ini berupa buku-buku penunjang, foto-foto ketika melakukan wawancara, serta data penunjang lainnya.

Teknik analisis data yang digunakan dalam penelitian ini dilakukan melalui reduksi, display/ penyajian dan penarikan kesimpulan. Reduksi data dilakukan untuk merangkum, memilih hal yang pokok, memfokuskan hal yang penting dan membuang hal-hal yang tidak sesuai dengan tema. Dengan demikian data yang sudah direduksi akan memberikan gambaran yang lebih jelas. Display data dilakukan agar data dapat terorganisasi dalam pola hubungan yang mudah dipahami. Penyajian data dalam bentuk uraian singkat, hubungan antar kategori, dan sejenisnya yang terpenting digunakan dalam penyajian data dalam penelitian kualitatif ialah dengan teks yang bersifat naratif. Penarikan kesimpulan dilakukan dengan merumuskan hasil analisis dan pembahasan untuk menjawab pertanyaan yang diajukan dalam penelitian ini.

Teknik pengecekan keabsahan data yang akan digunakan dalam penelitian ini adalah sebagai upaya menyempurnakan serta mengoreksi kembali hasil yang telah didapatkan sesuai dengan rumusan masalah yang akan dibahas.

\section{Pembahasan}

\subsection{Bauran Pemasaran Sarana Upakara di Kawasan Pasar Tradisional Kota Mataram}

Berdasarkan hasil analisis data, dapat digambarkan bahwa bauran pemasaran adalah gambaran sederhana dari proses komunikasi yang memperlihatkan kaitan antara satu komponen komunikasi dengan komponen lainnya yang diterjadi dalam perdagangan sarana upakara di kawasan pasar tradisional Kota Mataram. Kemudian menghasilkan kegiatan komunikasi antara pedagang dalam memasarkan produk yang menjadi orientas 
dominan pada kebutuhan dan keinginan konsumen sebagai aktivitas dalam meningkatkan kekreatifitas pedagang yang meliputi perencanaan dari konsep penetapan harga, promosi, dan distribusi dari ide, produk, dan pelayanan dengan tujuan tidak hanya memuaskan pelanggan saat ini, melainkan mengantisipasi dan memenuhi kebutuhan mereka dimasa mendatang untuk mendapatkan suatu keuntungan.

Sehingga dalam penelitian ini menghasilkan kegiatan pemasaran yaitu (1) produk sarana upakara yang menjadi intensitas dominan yang lebih sering dibeli ialah berupa produk jejaitan yang terbuat dari busung ibung seperti jenis jejaitan sampian ajengan, gantung-gantungan, tamiang serta masih banyak jenis jejaitan lainnya yang digunakan dalam upakara persembahyangan. (2) Harga, dalam pemberian harga didasarkan pada jenis serta bentuk hasil yang diproduksi serta melihat intensitas pembelian yang dimana hal tersebut mengakibatkan perbedaan harga yang lebih meningkat pada hari-hari biasanya dari pada hari raya besar seperti hari raya galungan dan kuningan. (3) pedagang sarana upakara di kawasan pasar tradisoal Kota Mataram, khususnya pasar tradisonal Cakranegara dan pasar tradisonal Karang Lelede lebih memilih menggunakan media promosi secara langsung kepada konsumen atau personal selling dengan cara melalukan pemasaran kepada calon pembeli yang melewati lapak-lapak tempat berjualan dan memasarkan produk-produk yang dibutuhkan oleh pembeli serta memperlihatkan produk-produk yang dinginkan sebagai salah satu strategi dalam memenuhi kepuasan pembeli. (4) lokasi yang dipilih oleh pedagang sarana upakara ialah di kawasan pasar tradisional Cakranegara dan Karang Lelede dengan alasanya lokasi kedua pasar tersebut dikelilingi oleh lingkungan yang mayoritas masyarakatnya beragama Hindu yang sering membutuhkan sarana upakara seperti yang dijual oleh pedagang salah satunya yaitu jejaitan, sehingga mempermudah konsumen dalam menjangkau untuk memenuhi kebutuhannya dalam melakukan persiapan persembahyangan.

Proses dalam kegiatan komunikasi dua arah antara pedagang dengan pembeli sarana upakara mengambarkan elemen bauran pemasaran yang dilakukan oleh pedagang sarana upacara melalui tahap pemaknaan yaitu pedagang bertindak sebagai komunikator dengan memberikan pesan terkait produk, serta harga yang kemudian dikirimkan kepada pembeli sebagai komunikan melalui proses promosi secara langsung kehadapan pembeli 
di lokasi tempat berjualan. Tahap selainjutnya pembeli akan memahami serta memberikan respon Balik terhadap pesan yang disampaikan berupa kegiatan tawar menawar sampai menghasilkan keputusan berupa nilai yang telah disepakti kedua belah pihak. Kegiatan tersebut dapat memberikan kepuasan kedua belah pihak antara pedagang dan pembeli.

Kemudian dapat disimpulkan bahwa kegiatan pemasaran adalah aktifitas kreatifan pedagang yang meliputi perencanaan dari konsep penetapan harga, promosi yang digunakan, dan distribusi dari ide, produk yang dihasilkan, dan hal terpenting ialah pelayanan dalam komunikasi yang digunakan sebagai upaya menemukan kepuasan kedua belah pihak dengan tujuan tidak hanya memuaskan pelanggan saat ini, melainkan mengantisipasi dan memenuhi kebutuhan mereka dimasa mendatang untuk mendapatkan suatu keuntungan.

\subsection{Kendala Komunikasi Pemasaran Sarana Upakara Di Kawasan Pasar Tradisional}

\section{Kota Mataram}

Tujuan dari kegiatan komunikasi pemasaran meliputi tiga tujuan utama, yaitu untuk menyebarkan informasi (komunikasi informatif), mempengaruhi untuk melakukan pembelian atau menarik konsumen (komunikasi persuasif), dan mengingatkan khalayak untuk melakukan pembelian ulang (komunikasi mengingatkan kembali). Pada umumnya perusahaan yang berhasil adalah perusahaan yang melaksanakan konsep pemasaran yang berorientasi kepada konsumen, karena perusahaan inilah yang mampu menguasai pasar dalam jangka panjang. Dalam pandangan konsep pemasaran, tujuan perusahaan dicapai melalui kepuasan konsumen.

Dalam kegiatan komunikasi pemasaran sarana upakara di kawasan pasar tradisonal Kota Mataram, kendala-kendala yang muncul diakibatkan oleh beberapa faktor gangguan yang terjadi yakni pertama ialah gangguan teknis dimana dalam proses pembuat produk jejaitan yang diakibatkan dari kurang teliti dan kerapian dalam proses produksi mengakibatkan produk yang dihasilkan mengalami kerusakan dan daya beli konsumen menjadi berkurang.

Kedua gangguan dalam bahasa, perbedaan asal kelahiran serta bahasa kesehariharian yang digunakan mengakibatkan perbedaan makna dalam komunikasi yang tidak 
sejalan, begitu pula kendala yang terjadi dalam kegiatan pemasaran sarana upakara yang dilakukan oleh pedagang terhadap pembeli dalam memenuhi kebutuhan serta permintaan akibat dari pengunaan bahasa yang berbeda selain itu penyebutan terhadap produk yang memiliki penyembutan bahasa yang berbeda mengakibatkan proses interaksi komunikasi menjadi kurang efektif.

Ketiga gangguan dalam rintangan fisik terhadap kegiatan komunikasi pemasaran sarana upakara rintangan yang dimaksud ialah akibat dari lokasi distrubusi atau lokasi tempat pedagang memasarkan produk yang dijual terlalu kecil dan memiliki keterbatasan dalam konsumen untuk menjangkaunya sehingga mengakibatkan ketidaknyaman konsumen dalam melihat serta memilih produk yang dibutuhkan terutama dalam keadaan pengunjung rame.

Beberapa kendala yang diakibatakan oleh faktor-faktor gangguan yang terjadi mengakibatakan kegiatan dalam komunikasi pemasaran pedagang dan konsumen menjadi tidak efektif. Gangguan yang terjadi tersebut akibat dari distorsi yang tak terduga selama proses komunikasi yang mengakibatkan penerima memperoleh pesan berbeda dari yang dikirimkan pengirim. Sehingga kegiatan komunikasi antara pedagang dan pembeli menghasilkan feedback yang berbeda salah satunya dari perbedaan bahasa yang digunakan, selain itu ketidaknyaman lokasi dalam proses komunikasi pemasaran juga menjadikan hambatan.

Dalam kegiatan teori komunikasi dua arah feedback atau respon merupakan suatu hal yang penting terhadap keefektifan kegiatan komunikasi yang berlangsung, sehingga apabila terjadinya gangguan pada saat komunikasi itu berlangsung mengakibatkan komunikasi tersebut terputus dan tidak temukannya hasil dari komunikasi tersebut. Pernyataan teori tersebut sejalan dengan kendala yang dihadapi dalam komunikasi pemasaran yang berlangsung di kawasan pasar tradisional yang mengakibatkan komunikasi antara pedagang dengan konsumen terputus dari gangguan yang muncul pada penyampaian pesan akibat saluran komunikasi bermasalah.

\subsection{Implikasi Komunikasi Pemasaran Sarana Upakara di Kawasan Pasar Tradisional} Kota Mataram 
Kegiatan komunikasi pemasaran sarana upakara di kawasan pasar tradisonal Kota Mataram berdasarkan hasil analisis paparan data menimbulkan beberapa dampak positif serta dampak negatif. Dampak positif yang dirasakan kedua belah pihak antara konsumen dan pedagang diantaranya: (1) Bagi pedagang kegiatan pemasaran yang dilakukan dapat membantu meningkatkan perekonomian keluarga dan membuka lowongan pekerjaan bagi masyarakat disekelilingnnya. (2) Bagi konsumen dapat membantu dalam mempermudah memproleh produk sarana upakara dalam kegiatan upacara terutama pada konsumen yang kesulitan dalam memproduksi atau membuat sarana upakara khususnya pada produk jejaitan, sehingga merasa sangat terbantu dengan tersedianya produk-produk jejaitan yang dijual saat ini dengan lokasi yang strategis dan mudah dikunjungi.

Selain dampak positif, tentunya ada pula dampak negatif yang dirasakan oleh konsumen sebagai pengguna dan pembeli sarana upakara ialah hilangnya kebudayaan serta tradisi yang dilakukan dalam ritual kegiatan persiapan upacara yaitu tradisi mejejaitan yang semakin lama semakin memudar dan menghilag dikalangan remaja saat ini, akibat pengaruh globalisasi yang sekarang sudah mudah didapatkan dibandingkan harus membuatnya sendiri karena memerlukan waktu yang lumayan lama.

Munculnya kegiatan komunikasi dalam aktivitas pemasaran sarana upakara yang berada di kawasan pasar tradisonal mengacu terhadap teori difusi inovasi yang dimana sebuah ide atau gagasan yang baru terbentuk berasal dari sebuah kebudayaan sebagai proses difusi dimana sebuah inovasi tersebut dikomunikasikan melalui berbagai saluran yang ada untuk membantu suatu kebutuhan yang meningkat akibat dari pergerakan globalisasi. Teori ini meyakini bahwa sebuah inovasi terdifusi keseluruh masyarakat dalam pola yang bisa diprediksi. Beberapa kelompok orang akan mengadopsi sebuah inovasi segera setelah mereka mendengar inovasi tersebut. Sedangankan beberapa kelompok masyarakat lainnya membutuhkan waktu lama untuk kemudian mengadopsi inovasi tersebut.

Dalam teori ini ada 5 (lima) tahap proses difusi inovasi yang terjadi dalam kegiatan komunikasi pemasaran sarana upakara di kawasan pasar tradisonal Kota Mataram yang dapat dilihat dari, (1) Kesadaran masyarakat akan tingginya kebutuhan khusus dalam proses persiapan pelaksanaan yadnya akibat dari pengaruh globalisasi yang 
mengakibatkan keterbatasan waktu oleh sebagian orang yang bekerja diperkantoran sehingga menimbulkan sebuah inovasi yang dilakukan pedagang dalam menyedikan sarana upakara salah satunya dalam produk jejaitan sebagai fungsi untuk memudahakan masyarakat yang sedang membutuhkan kepraktisan dalam melakukan persiapan persembahyangan khusus dalam membuat banten persembahan melalui elemen-elemn di dalam bauran pemasaran sebagai kegiatan dalam aktivitas komunikasi pemasaran yang akan dilakukan. (2) Kemunculan inovasi tersebut menimbulkan dampak positif yang diterima oleh masyarakat Hindu, salah satu bentuk penerimaan terhadap produk yang dipasarkan yaitu dilihat intensitas tingginya permintaan terhadap salah satu produk yang dihasilkan yaitu jejaitan. (3) Keputusan yang membawa pedagang mulai mengadopsi inovasi tersebut ialah karena faktor permintaan serta sebagai bentuk pengaplikasian pengetahuan dan keterampilan yang dimilikinya untuk digunakan dalam ranah, yaitu masyarakat. Sebagai modal budaya yang secara terus menerus dikembangkan hingga menjadi modal ekonomi. (4) Dalam pelaksaannya, pemilihan pemasaran sarana upakara tersebut didasarkan akan pilhan serta kemampuan yang dimiliki setiap pedagang dalam menghasilkan produk dikarenakan modal budaya yang sudah didapatkan sejak dini berhubungan dengan tradisi mejejaitan sebagai aktivitas untuk menghasilkan sebuah produk jejaitan yang kemudian akan dipasarkan menjadi barang yang bernilai komoditi (nilai tukar). (5) Dalam mengadopsi sebuah inovasi seorang pedagang sarana upakara memasarkan hasil produk yang telah dihasilkannya sebagai bentuk perubahan fungsi yang telah dihasilkannya dari menjadi nilai guna bertambah menjadi nilai tukar, dimana jika respon yang dipasarkan mendapatkan tanggapan positif dari para konsumen yang membelinya membuat keyakinan akan suatu inovasi untuk terus berkembang.

\section{IV.Simpulan}

Berdasarkan hasil penelitian ini dapat dirumuskan simpulan terkait dengan Komunikasi Pemasaran sarana upakara di kawasan pasar tradisional di Kota Mataram sebagai berikut:

Pertama, bauran pemasaran sarana upakara di kawasan pasar tradisonal Kota Mataram yakni menggambarkan suatu kegiatan pemasaran yang terdapat dalam elemen- 
SADHARANANIKARANA:

Jurnal Ilmiah Komunikasi Hindu Institut Agama Hindu Negeri Gde Pudja Mataram
Volume 3, Nomor 1 Tahun 2021 2338-8382 (ISSN Cetak) https://e-journal.iahn-gdepudja.ac.id/index.php/SN

elemen bauran pemasaran 4P diantaranya: (1) produk sarana upakara yang menjadi intensitas dominan yang lebih sering dibeli ialah berupa produk jejaitan (2) Dalam pemberian harga didasarkan pada jenis serta bentuk hasil yang diproduksi serta melihat intensitas pembelian. (3) pedagang sarana upakara di kawasan pasar tradisoal Kota Mataram, lebih memilih menggunakan media promosi secara langsung kepada konsumen atau personal selling (4) lokasi yang dipilih oleh pedagang sarana upakara ialah di kawasan pasar yang dikelilingi oleh lingkungan yang mayoritas beragama Hindu.

Kedua, kendala yang dihadapi dalam komunikasi pemasaran sarana upakara di kawasan pasar tradisonal yaitu (1) terdapat kecacatan terhadap produk yang dihasilkan, (2) kendala akibat perbedaan bahasa dalam berkomunikasi (3) terhadap lokasi yang tidak strategis dikarenakan lokasi tempat berjualan ditutupi oleh pedagang lain yang mengakibatkan kegiatan komunikasi menjadi tidak efektif.

Ketiga, implikasi yang terjadi dalam kegiatan komunikasi pemasaran sarana upakara di kawasan pasar tradsional Kota Mataram terdiri dari pengaruh positif dan negatiif dimana pengaruh positifnya antara lain, (1) Bagi pedagang kegiatan pemasaran yang dilakukan dapat membantu meningkatkan perekonomian keluarga dan membuka lowongan pekerjaan bagi masyarakat disekelilingnnya. (2) Bagi konsumen dapat membantu dalam mempermudah memproleh produk sarana upakara dalam kegiatan upacara terutama pada konsumen yang kesulitan dalam memproduksi atau membuat sarana upakara khususnya pada produk jejaitan, sehingga merasa sangat terbantu dengan tersedianya produk-produk jejaitan yang dijual saat ini dengan lokasi yang strategis dan mudah dikunjungi. Kemudian pengaruh negatifnya tinggkat kesadaran dan nilai kebudayaan dan seni dalam kegiatan persiapan upacara dalam bentuk mejejaitan lambat laut mulai berkurang dan hilang, akibat ketertaringan orang lebih kepada membeli ketimbang membuatnya.

\section{Daftar Pustaka}

Ari, dkk, 2015. Prinsip-Prinsip Pemasaran, Yogyakarta, Andi Yogyakarta. Hal 371-372. Arwati, Ni Made Sri. 1992. Upacara Upakara. Denpasar: Upada Sastra.

Cangara, Hafied (2019). Pengantar Ilmu Komunikasi, Edisi Keempat. Depok: PT. Raja Grafindo Persada 
Chirsmadadi, 2014. Komunikasi Pemasaran Terpadu Implikasi Untuk UMKM. Dalam jurnal Ne0-Bis, Volume 8, Nomor 2.

Daryanto, 1997. Kamus Bahasa Indonesia Lengkap. Surabaya: Apollo.

Devito, J. A. 2011. Komunikasi Antarmanusia Edisi Kelima. Penerbit Karisma Publishing Group : Tangerang Selatan.

Burhan Bungin, 2009. Sosiologi Komunikasi. Jakarta. Hal : 285

Effendy, Onong Uchjana (1984). Ilmu Komunikasi, Teori dan Praktek. Bandung: PT Remaja Rosdakarya

Gadiza Lombok, 2018. Berburu Oleh-Oleh Murah Di Pasar Cakranegara Lombok. Available at : https://www.gadizalombok.com/2018/10/08/berburu-oleh-olehmurah-di-pasar-Cakranegara-lombok/. Diakses pada 20 Oktober 2020.

Morissan. 2010. Periklanan: Komunikasi Pemasaran Terpadu. Jakarta: Prenada Media Group.

. 2013, Teori komunikasi: Individu Hingga Massa, Jakarta : Kencana Prenada Media Group. Hal : 16.

Pelayanan Publik. 2019. Pengertian Sarana dan Prasarana, Fungsi Hingga Contohnya. Available at: https://pelayananpublik.id/2019/08/12/pengertian-sarana-danprasarana-fungsi-hingga contohnya/\#: : :text=KBBI\%20menyatakan\%20bahwa\%20sarana\%20adalah,us aha\%2C\%20pembangunan\%2C\%20proyek). Diakses tanggal 23 Juni 2020.

Pemkab Buleleng. 2019. Memahami Makna Pentingnya Sarana Upakara Agama Hindu (Banten). Available at: https://www.bulelengkab.go.id/detail/artikel/memahami-makna-pentingnyasarana-Upakara-agama-Hindu-banten-19. Diakses pada 16 Juli 2020.

Rogers Everett M. and Schoemaker Floyd F. 1983. Diffusion and Innovation. Free Press, New York.

Safitri, N.A .2017. Strategi komunikasi Pemasaran Untuk Meningkatkan Daya Beli Konsumen Melalui Sosial media. Jurnal Kompetensi, Vol 11, No 2 : 210-216. 
SADHARANANIKARANA:

Jurnal Ilmiah Komunikasi Hindu Institut Agama Hindu Negeri Gde Pudja Mataram
Volume 3, Nomor 1 Tahun 2021 2338-8382 (ISSN Cetak)

https://e-journal.iahn-gdepudja.ac.id/index.php/SN

Saputra, Hendra. 2008. Analisis Pengaruh Strategi Bauran Pemasaran Terhadap Pemutusan Pembelian Teh Celup Sariwagi Oleh Konsumen Rumah Tangga di Kota Medan.

Subagiasta, I Ketut. (2008). Pengantar Acara Agama Hindu. Surabaya: Paramita.

Sudaharta, Tjok Rai. (2007). Upadsa Tentang Ajaran-Ajaran Agama Hindu.

Suherman, (2016). "Strategi Komunikasi Pemasaran Dalam Kegiatan Pemasan Produk Consumer Goods". Jurnal Komunikasi, Volume 8, Nomor 1.

Suprapto, Tommy, 2006. Pengantar Teori Komunikasi. Yogyakarta: Media Pressindo. 